\title{
KNOWLEDGE OF PARENTS OF CHILDREN WITH AUTISM FROM POLAND, BELARUS AND FRANCE CONCERNING THEIR CHILD'S CONDITION
}

\section{WIEDZA RODZICÓW DZIECI Z AUTYZMEM Z POLSKI, BIAŁORUSI I FRANCJI NA TEMAT CHOROBY DZIECKA}

\author{
Anna Ślifirczyk ${ }^{1(\mathrm{~A}, \mathrm{C}, \mathrm{G})}$, Elżbieta Krajewska-Kułak ${ }^{2(\mathrm{E}, \mathrm{F})}$, Martyna Krukowska $^{1(\mathrm{~B}, \mathrm{D})}$, \\ Elżbieta Maciorkowska ${ }^{3(\mathrm{~A}, \mathrm{C})}$
}

\begin{abstract}
${ }^{1}$ Faculty of Health and Social Sciences, Pope John Paul II State School of Higher Education in Biała Podlaska, Poland
${ }^{2}$ Department of Integrated Medical Care, Medical University of Bialystok, Poland

${ }^{3}$ Department of Developmental Age Medicine and Paediatric Nursing, Medical University of Bialystok, Poland
\end{abstract}

Authors' contribution Wkład autorów:

A. Study design/planning zaplanowanie badań B. Data collection/entry zebranie danych C. Data analysis/statistics dane - analiza i statystyki D. Data interpretation interpretacja danych E. Preparation of manuscript przygotowanie artykułu F. Literature analysis/search wyszukiwanie $i$ analiza literatury G. Funds collection zebranie funduszy
Background. Autism is not only a problem for people with autism, but also for their entire families. Material and methods. 83 families were analysed, including 30 families from Poland, 25 families from Belarus and 28 families from France, an author's questionnaire was used. Results. The majority of respondents were aware of the fact that autism can also be diagnosed in an adult person. Likewise, the notion of the autistic spectrum was known. While parents from Poland and France realised that a one-time diagnosis of the condition is insufficient, parents from Belarus more often chose the incorrect answer, and therefore they express the tendency to immediately start a therapy without additional consultations. All respondents from France chose the statement that treatment of autism should be started before the age of 3, which was confirmed by the majority of respondents from the other two countries. Polish parents barely considered the importance of preparation required to understand their child's behaviour, whereas this aspect of the therapy was indicated by almost $90 \%$ of the respondents from the other two countries. Parents from Poland (69\%) and Belarus $(76 \%)$ were mostly convinced that autism cannot be cured completely. A different opinion was expressed by $42.9 \%$ of parents from France, who were convinced about it. The Poles most willingly used the Internet as a source of knowledge, while the French and Belarusians - a psychologist. A paediatrician was a preferred educator in Poland, in Belarus and France - a psychologist. Conclusions. The parents of autistic children, regardless of the country, showed a low level of knowledge about autism. The vast majority of respondents declared a desire to deepen their knowledge on autism, expressing their preference to have an individual conversation with an educator.

Keywords: autism, parents, knowledge

\section{Streszczenie}

Wprowadzenie. Autyzm nie jest problemem jedynie osób z autyzmem, ale również całych ich rodzin. Materiał i metody. Analizie poddano 83 rodziny, w tym 30 rodzin z Polski, 25 rodzin z Białorusi oraz 28 rodzin z Francji i wykorzystano kwestionariusz autorski. Wyniki. Większość ankietowanych wiedziała, że autyzm można zdiagnozować także u osoby dorosłej, znane było także pojęcie spektrum autystycznego. 0 ile rodzice z Polski i Francji zdawali sobie sprawę, że jednorazowa diagnoza choroby jest niewystarczająca, to rodzice z Białorusi częściej wybierali błędną odpowiedź, a więc natychmiastowe rozpoczęcie terapii bez dodatkowych konsultacji. Wszyscy ankietowani z Francji wybierali stwierdzenie, iż leczenie autyzmu należy zaczać przed 3 rokiem życia, co potwierdziło większość ankietowanych z pozostałych dwóch krajów. Rodzice $\mathrm{z}$ Polski ledwie $\mathrm{w}$ połowie za ważne uznali przygotowanie rodziców do zrozumienia zachowań dziecka, podczas gdy ten aspekt terapii wskazało niemal 90\% ankietowanych z dwóch pozostałych krajów. Rodzice z Polski (69\%) i Białorusi (76\%) byli w większości przekonani, iż autyzmu nie można wyleczyć całkowicie. Odmienną opinię wyraziło $42,9 \%$ przekonanych o tym rodziców z Francji. Polacy najchętniej jako źródło wiedzy wykorzystywali Internet, Francuzi i Białorusini - psychologa. Za edukatora w Polsce preferowano pediatrę, na Białorusi i we Francji - psychologa. Wnioski. Rodzice dzieci autystycznych, niezależnie od kraju, wykazywali niski poziom wiedzy na temat autyzmu. Zdecydowana większość respondentów deklarowała chęć pogłębienia wiedzy na temat autyzmu preferując $w$ tym celu rozmowę indywidualną z edukatorem.

Słowa kluczowe: autyzm, rodzicie, wiedza
Tables: 2
Figures: 0

References: 22

Submitted: 2017 Sept 13

Accepted: 2018 May 17

Ślifirczyk A, Krajewska-Kułak E, Krukowska M, Maciorkowska E. Knowledge of parents of children with autism from Poland, Belarus and France concerning their child's condition. Health Prob Civil. 2019; 13(2): 114-122. https://doi.org/10.5114/hpc.2018.80228

Address for correspondence / Adres korespondencyjny: Anna Ślifirczyk, Faculty of Health and Social Sciences, Pope John Paul II State School of Higher Education, Sidorska 95/97, 21-500 Biała Podlaska, Poland, e-mail: aslifirczyk1@gmail.com, phone: +48 508238088

ORCID: Anna Ślifirczyk https://orcid.org/0000-0002-2495-025X, Elżbieta Krajewska-Kułak https://orcid.org/0000-0002-9425-2430,

Martyna Krukowska https://orcid.org/0000-0003-4589-3626, Elżbieta Maciorkowska https://orcid.org/0000-0002-5118-8440

Copyright: (C) Pope John Paul II State School of Higher Education in Biała Podlaska, Anna Ślifirczyk, Elżbieta Krajewska-Kułak, Martyna Krukowska, Elżbieta Maciorkowska. This is an Open Access journal, all articles are distributed under the terms of the Creative Commons Attribution-NonCommercial-ShareAlike 4.0 International (CC BY-NC-SA 4.0) License (http://creativecommons.org/licenses/by-nc-sa/4.0/), allowing third parties to copy and redistribute the material in any medium or format and to remix, transform, and build upon the material, provided the original work is properly cited and states its license. 


\section{Introduction}

Children's autism is a developmental disorder, present in almost all communities, which is characterized by abnormalities in the development of social interactions, communication and serious limitations in terms of activity and interests [1].

The progress in the diagnosis of the disorder has caused an increase in the frequency of diagnoses of children with autism in the world (in 1970 - 1 case per 10,000 births, and in 2009 - 1 case per 150 births), which means that the number of families involved in the care, upbringing and education of children with autism is also rapidly increasing [2, 3].

The first epidemiological study on autism was completed in 1966 in Great Britain and was carried out by Lotter [4] in Middlesex County.

In the literature $[5,6,7]$ it is emphasised that the difficulty of defining autism lies in the fact that the phenomenon itself is a complex problem, and the diagnostic perspectives adopted make it possible to perceive only its individual fragments, which, when considered in their entirety, form a meaningful whole.

It is not easy to be a parent of an autistic child, since more often it is connected with experiencing very difficult moments. Moreover, frequently such guardians are close to a breakdown and simply do not know what to do, how to proceed, where to ask for help, how to teach their child.

The development of an autistic child is different from that of their peers. According to Greenberg et al. [8], such parents need reliable knowledge, so that they can efficiently motivate the child to act and help them overcome difficulties. Taking care of a sick child and their upbringing requires patience, perseverance and entrepreneurship in obtaining the help of specialists and skills to cope with difficult situations. The involvement and dedication of parents in the hardship of caring for an autistic child and the atmosphere in the family affect the functioning of a sick child. It has been observed that the high level of negative emotions in the family system causes the intensification of maladaptive behaviours and other symptoms of autism [8].

Therefore, one of the tasks of specialists is to support parents in creating a coherent and realistic picture of their child, in order to help them strengthen their sense of satisfaction with the achieved successes and to increase their awareness and level of knowledge.

In the literature on the subject [9-13], it is emphasized that contemporary activities are aimed at the greatest possible activation and involvement of parents in the therapeutic process of children. In this respect, attention is drawn to the importance of professional therapeutic programmes aimed at parents of children with autism. On the one hand, they are based on directing parents to active participation and cooperation in the activities conducted with autistic children, and on the other, on deepening their teaching skills and causing the change in their behaviour.

Unfortunately, in the professional literature there are sporadic studies concerning parents' knowledge of autism and their preparation for cooperation with such a child.

The aim of the study was to assess the knowledge of parents of children with autism from Poland, Belarus and France on the subject of a child's condition.

It was hypothesised that parents to a large extent show interest in the knowledge about their child's condition, mainly in the field of forms of therapy.

\section{Material and methods}

The study was carried out after obtaining the consent No. RI-002/242/2009 of the Bioethics Committee of the Medical University in Bialystok.

Parents of children diagnosed with autistic disorder were subjected to a questionnaire survey. The parents came from three European countries: Poland, Belarus and France, while the attempt was made to make the numerical structure with regard to the origin similar. The following inclusion criteria have been adopted: joint living with a child now and throughout the entire period of the condition, being biological parents, diagnosed (according to ICD 10 or DSM IV) and documented chronic disorder, with its minimum duration of 3 years and consent to the study. Furthermore, the exclusion criterion was the lack of consent to the study.

83 families were analysed, including 30 families from Poland, 25 families from Belarus and 28 families from France.

The study was based on an author's questionnaire, which consisted of general and fundamental questions composed of 18 questions, among others: knowledge of the percentage of the population affected by autism, most affected gender, the possibility of its diagnosis in adults, knowledge of the concept of autistic spectrum, symptoms of autism, evaluation of myths about autism, the period in which a therapy should be started, opinions on the treatment of autism with a diet, the existence of effective medicines, the possibility of curing autism completely, whether a one-time medical examination is sufficient to diagnose "autism", sources of knowledge 
about autism, the need to expand the knowledge in this area, preferred individuals who should provide parents with knowledge about autism, topics they would like to have discussed in the field of autism, preferred forms of communication of such knowledge.

The study was carried out in 2011-2012. In total, 30 questionnaires were distributed in Poland and 30 were used in the study, 30 questionnaires were distributed in Belarus and 25 were used, while in France, 30 questionnaires were distributed and 28 were used.

In view of the nature of the data, the chi-squared test was considered an appropriate tool for statistical inference. Based on the result of the test ( $p$-value test), which is included in the header of the table, it was concluded that the studied dependence between the country and the approach to the disease was statistically significant. It has been assumed that when $p^{3}$ is 0.05 it indicates that the tested difference, dependence, effect, it was not statistically significant; when $p<0.05$ we talk about statistically significant dependence (we mark this fact with ${ }^{*}$ ); $p<0.01$ is a highly significant dependence $(* *) ; p<0.001$ is a very highly statistically significant dependence $(* * *)$.

\section{Results}

Parents in Poland have mainly resided in the city (57.7\%), the rest (42.3\%) in the rural areas. Parents from Belarus - also mainly resided in the city (88\%) and a small percentage (12\%) in rural areas, and parents from France - primarily in the city (74.1\%), and only $25.9 \%$ in rural areas. Generally, the mothers studied were a few years younger (means age was $36.2 \pm 6.7$ years) from their spouses (39.4 \pm 7.5 years). The mean age of fathers in Poland was $42.7 \pm 8.0$ years, in Belarus - 38.1 \pm 6.9 years, and in France - 37.1 \pm 6.4 years. The mean age of mothers in Poland was $38.4 \pm 6.8$ years, in Belarus - $36.0 \pm 6.2$ years, and in France $-34.1 \pm 6.5$ years. The mean time from the diagnosis of autism in a child in Poland was $7.9 \pm 2.7$ years, in Belarus mean age was $7.2 \pm 5.2$ years, and in France $-5.2 \pm 3.2$ years.

In the next part of the paper, the authors attempted to present the information on the level of parents' knowledge about autism, taking into account the country of their origin.

25\% of parents from Poland, 4.3\% of parents from Belarus and 3.6\% from France have correctly defined the percentage of the world population suffering from autism as $0.5 \% .50 \%$ of respondents from Poland, $34.8 \%$ from Belarus and 3.6\% from France were convinced that the value isbetween 0.5 to $1 \%$ of the population. $7.1 \%$ of respondents from Poland, 8.7\% from Belarus and 14.3\% from France believed that the problem of autism concerns over $10 \%$ of the population. $17.9 \%$ of respondents from Poland, $52.2 \%$ from Belarus and $14.3 \%$ from France had a problem with an unambiguous response. The distribution of responses differed significantly between the countries ( $\left.\mathrm{p}=0.0000^{* * *}\right)$.

Regarding the question about the determination of a gender that is more vulnerable to autism, Polish parents have provided the most incorrect answers, as $53.2 \%$ of parents from Poland, $83.3 \%$ of parents from Belarus and $78.6 \%$ of parents from France were convinced that the boys are mainly affected by the disease. The girls were indicated by $10 \%$ of respondents from Poland and $17.9 \%$ from France. About $10 \%$ of parents from Poland and 3.6\% from France were convinced that the same percentage of both genders was concerned. $26.7 \%$ of respondents from Poland and $16.7 \%$ from Belarus did not express an unambiguous opinion on this matter. The distribution of responses differed significantly between the countries $\left(p=0.0122^{*}\right)$.

The majority of respondents were correct to indicate that autism can also be diagnosed in an adult person - 69\% of parents from Poland, 52\% from Belarus and 78.6\% from France stated that. A different opinion was expressed by $3.4 \%$ of the respondents from Poland and $4 \%$ from Belarus. $27.6 \%$ of the respondents from Poland, 44\% from Belarus and 21.4\% from France were undecided on this issue. The distribution of responses did not differ significantly between the countries ( $p=0.3086)$.

The autistic spectrum, as a general name for all forms of autism, was well defined by $96 \%$ of parents from Poland, 94.6\% from Belarus and 96.2\% from France. Concerning the group of colours, which autistic children do not distinguish, it was correctly defined by $4 \%$ of respondents from Poland and $3.8 \%$ from France, and as a device to stimulate positive behaviours of a child - 5.3\% from Belarus. The distribution of responses did not differ significantly between the countries $(p=0.4881)$.

While the parents from Poland (70\%) and France (72\%) were mostly aware that a one-time diagnosis of the condition was insufficient, parents from Belarus were less convinced about it (40\%). The latter preferred to start the treatment immediately (60\%), which was supported by $23.3 \%$ of parents from Poland and $4 \%$ from France. $6.7 \%$ of Polish parents and $24 \%$ of French parents were advocates of waiting two years after the specialist's diagnosis and repeating the examination. The distribution of responses differed significantly between the countries $\left(\mathrm{p}=0.0001^{* * *}\right)$. 
Table 1. shows the parents' responses to the question about the most recognizable symptoms of autism. Polish parents most often mentioned the delayed speech development (73.3\%) and the development delay (63.3\%). Parents from Belarus - repetition of the same activities (96\%), and parents from France - obsessive repetition of behaviours (82.1\%). Details are provided in Table 1.

Table 1. Symptoms of autism

\begin{tabular}{|l|c|c|c|c|}
\hline \multirow{2}{*}{\multicolumn{1}{|c|}{ Symptoms of autism }} & \multicolumn{2}{c}{ Country } & p \\
\cline { 2 - 4 } & Poland & Belarus & France & $0.0009^{* * *}$ \\
\hline delayed speech development & $\mathbf{7 3 . 3 \%}$ & $24.0 \%$ & $60.7 \%$ & 0.2451 \\
\hline impaired social communication & $50.0 \%$ & $68.0 \%$ & $46.4 \%$ & 0.5071 \\
\hline no response to the name, commands & $56.7 \%$ & $56.0 \%$ & $42.9 \%$ & $0.0009^{* * *}$ \\
\hline repeating the same activities & $50.0 \%$ & $\mathbf{9 6 . 0 \%}$ & $60.7 \%$ & 0.2653 \\
\hline fluttering with hands & $46.7 \%$ & $56.0 \%$ & $67.9 \%$ & $0.0055^{* *}$ \\
\hline attachment to routine & $43.3 \%$ & $28.0 \%$ & $71.4 \%$ & $0.0298^{*}$ \\
\hline tantrums, fury & $30.0 \%$ & $52.0 \%$ & $64.3 \%$ & 0.7080 \\
\hline lack of natural fear & $46.7 \%$ & $36.0 \%$ & $39.3 \%$ & 0.6714 \\
\hline sleep, nutrition disorders & $43.3 \%$ & $32.0 \%$ & $35.7 \%$ & 0.0784 \\
\hline the impression of absence & $56.7 \%$ & $36.0 \%$ & $28.6 \%$ & 0.0623 \\
\hline bed-wetting & $33.3 \%$ & $8.0 \%$ & $17.9 \%$ & 0.1232 \\
\hline biting & $50.0 \%$ & $32.0 \%$ & $25.0 \%$ & 0.4388 \\
\hline mental numbness & $23.3 \%$ & $20.0 \%$ & $10.7 \%$ & $0.0144^{*}$ \\
\hline no response to commands & $50.0 \%$ & $52.0 \%$ & $17.9 \%$ & $0.0094^{* *}$ \\
\hline delay in development & $\mathbf{6 3 . 3 \%}$ & $80.0 \%$ & $39.3 \%$ & $0.0057^{* *}$ \\
\hline pedantry & $13.3 \%$ & $36.0 \%$ & $3.6 \%$ & 0.4300 \\
\hline unwillingness to change in routine & $26.7 \%$ & $36.0 \%$ & $42.9 \%$ & $0.0001^{* * *}$ \\
\hline low / excessive sensitivity to stimuli & $20.0 \%$ & $16.0 \%$ & $64.3 \%$ & $0.0000^{* * *}$ \\
\hline obsessive repetition of behaviours & $10.0 \%$ & $68.0 \%$ & $\mathbf{8 2 . 1 \%}$ & \\
\hline
\end{tabular}

Table 2. presents a detailed analysis of the answer to the question concerning the truthfulness of certain statements about autism in the consciousness of the respondents from different countries. On many issues statistically significant differences were observed between the respondents from Poland, Belarus and France.

Table 2. Characteristics of autistic children

\begin{tabular}{|c|c|c|c|c|c|c|c|c|c|c|c|c|c|}
\hline \multirow[b]{3}{*}{$\begin{array}{l}\text { Characteristics of autistic } \\
\text { children }\end{array}$} & \multicolumn{12}{|c|}{ Country } & \multirow[b]{3}{*}{$\mathbf{p}$} \\
\hline & \multicolumn{4}{|c|}{ Poland } & \multicolumn{4}{|c|}{ Belarus } & \multicolumn{4}{|c|}{ France } & \\
\hline & $\stackrel{y}{\partial}$ & @ & 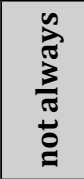 & 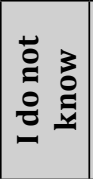 & $\stackrel{y}{2}$ & @ & 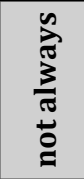 & 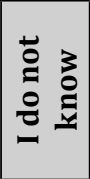 & $\stackrel{d}{z}$ & $@$ & 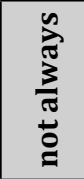 &  & \\
\hline they do not hug & $7 \%$ & $50 \%$ & $40 \%$ & $3 \%$ & $4 \%$ & $29 \%$ & $42 \%$ & $25 \%$ & $14 \%$ & $54 \%$ & $32 \%$ & $0 \%$ & $0.0200^{*}$ \\
\hline they do not look in the eyes & $23 \%$ & $20 \%$ & $57 \%$ & $0 \%$ & $16 \%$ & $8 \%$ & $76 \%$ & $0 \%$ & $68 \%$ & $7 \%$ & $21 \%$ & $4 \%$ & $0.0004^{* * *}$ \\
\hline autism only affects children & $3 \%$ & $55 \%$ & $31 \%$ & $10 \%$ & $0 \%$ & $58 \%$ & $21 \%$ & $21 \%$ & $4 \%$ & $79 \%$ & $11 \%$ & $7 \%$ & 0.3070 \\
\hline $\begin{array}{l}\text { all autistic children behave } \\
\text { the same }\end{array}$ & $0 \%$ & $73 \%$ & $27 \%$ & $0 \%$ & $4 \%$ & $76 \%$ & $20 \%$ & $0 \%$ & $0 \%$ & $56 \%$ & $44 \%$ & $0 \%$ & 0.4208 \\
\hline they are aggressive & $3 \%$ & $27 \%$ & $67 \%$ & $3 \%$ & $0 \%$ & $24 \%$ & $76 \%$ & $0 \%$ & $4 \%$ & $22 \%$ & $70 \%$ & $4 \%$ & 0.9144 \\
\hline $\begin{array}{l}\text { autism is caused by the } \\
\text { mother's attitude }\end{array}$ & $0 \%$ & $47 \%$ & $43 \%$ & $10 \%$ & $4 \%$ & $54 \%$ & $13 \%$ & $29 \%$ & $4 \%$ & $93 \%$ & $4 \%$ & $0 \%$ & $0.0001^{* * *}$ \\
\hline $\begin{array}{l}\text { people with autism do not } \\
\text { speak }\end{array}$ & $10 \%$ & $23 \%$ & $57 \%$ & $10 \%$ & $4 \%$ & $40 \%$ & $56 \%$ & $0 \%$ & $4 \%$ & $48 \%$ & $44 \%$ & $4 \%$ & 0.3125 \\
\hline $\begin{array}{l}\text { if someone can speak, it is } \\
\text { not autism }\end{array}$ & $10 \%$ & $43 \%$ & $40 \%$ & $7 \%$ & $0 \%$ & $72 \%$ & $24 \%$ & $4 \%$ & $7 \%$ & $86 \%$ & $7 \%$ & $0 \%$ & $0.0224^{*}$ \\
\hline $\begin{array}{l}\text { they avoid people, they } \\
\text { isolate themselves }\end{array}$ & $7 \%$ & $47 \%$ & $43 \%$ & $3 \%$ & $8 \%$ & $24 \%$ & $60 \%$ & $8 \%$ & $57 \%$ & $7 \%$ & $36 \%$ & $0 \%$ & $0.0000^{* * *}$ \\
\hline
\end{tabular}




\begin{tabular}{|c|c|c|c|c|c|c|c|c|c|c|c|c|c|}
\hline autistic children are calm & $7 \%$ & $37 \%$ & $57 \%$ & $0 \%$ & $12 \%$ & $8 \%$ & $80 \%$ & $0 \%$ & $36 \%$ & $18 \%$ & $46 \%$ & $0 \%$ & $0.0166^{*}$ \\
\hline $\begin{array}{l}\text { people with autism create } \\
\text { their own world }\end{array}$ & $23 \%$ & $27 \%$ & $33 \%$ & $17 \%$ & $48 \%$ & $8 \%$ & $16 \%$ & $28 \%$ & $71 \%$ & $4 \%$ & $25 \%$ & $0 \%$ & $0.0009^{* * *}$ \\
\hline $\begin{array}{l}\text { children with autism tend to } \\
\text { tum various objects }\end{array}$ & $20 \%$ & $30 \%$ & $50 \%$ & $0 \%$ & $60 \%$ & $4 \%$ & $36 \%$ & $0 \%$ & $71 \%$ & $18 \%$ & $11 \%$ & $0 \%$ & $0.0021^{* *}$ \\
\hline $\begin{array}{l}\text { people with autism are } \\
\text { exceptionally talented }\end{array}$ & $3 \%$ & $28 \%$ & $59 \%$ & $10 \%$ & $20 \%$ & $0 \%$ & $68 \%$ & $12 \%$ & $50 \%$ & $4 \%$ & $46 \%$ & $0 \%$ & $0.0001^{* * *}$ \\
\hline autism is incurable & $4 \%$ & $8 \%$ & $24 \%$ & $4 \%$ & $48 \%$ & $20 \%$ & $8 \%$ & $24 \%$ & $48 \%$ & $44 \%$ & $8 \%$ & $0 \%$ & $0.0236^{*}$ \\
\hline $\begin{array}{l}\text { autism is associated } \\
\text { mental retardation }\end{array}$ & $3 \%$ & $7 \%$ & $57 \%$ & $3 \%$ & $12 \%$ & $36 \%$ & $48 \%$ & $4 \%$ & $25 \%$ & $21 \%$ & $54 \%$ & $0 \%$ & 0.2582 \\
\hline $\begin{array}{l}\text { autistic children do not } \\
\text { understand what is being } \\
\text { said to them }\end{array}$ & $10 \%$ & $31 \%$ & $52 \%$ & $7 \%$ & $0 \%$ & $44 \%$ & $56 \%$ & $0 \%$ & $4 \%$ & $11 \%$ & $81 \%$ & $4 \%$ & .0607 \\
\hline children grow out of autism & $\%$ & $0 \%$ & $3 \%$ & $0 \%$ & $4 \%$ & $67 \%$ & $13 \%$ & $17 \%$ & $0 \%$ & $86 \%$ & $14 \%$ & $0 \%$ & 2003 \\
\hline $\begin{array}{l}\text { the child should be sent to } \\
\text { kindergarten }\end{array}$ & $17 \%$ & $34 \%$ & $41 \%$ & $7 \%$ & $42 \%$ & $17 \%$ & $38 \%$ & $4 \%$ & $0 \%$ & $82 \%$ & $11 \%$ & $7 \%$ & $0.0000^{* * *}$ \\
\hline $\begin{array}{l}\text { autism is a form of } \\
\text { schizophrenia, a mental } \\
\text { illness }\end{array}$ & $7 \%$ & $55 \%$ & $24 \%$ & $14 \%$ & $32 \%$ & $28 \%$ & $16 \%$ & $24 \%$ & $14 \%$ & $61 \%$ & $25 \%$ & $0 \%$ & $0.0178^{*}$ \\
\hline $\begin{array}{l}\text { people with autism have no } \\
\text { ambition, no sense of dignity }\end{array}$ & $21 \%$ & $31 \%$ & $38 \%$ & $10 \%$ & $17 \%$ & $26 \%$ & $30 \%$ & $26 \%$ & $64 \%$ & $7 \%$ & $29 \%$ & $0 \%$ & $0.0008^{* * *}$ \\
\hline $\begin{array}{l}\text { children with autism are not } \\
\text { interested in other children }\end{array}$ & $17 \%$ & $40 \%$ & $40 \%$ & $3 \%$ & $8 \%$ & $33 \%$ & $50 \%$ & $8 \%$ & $14 \%$ & $11 \%$ & $75 \%$ & $0 \%$ & 0.0788 \\
\hline $\begin{array}{l}\text { they do not have any } \\
\text { interests }\end{array}$ & $3 \%$ & $40 \%$ & $43 \%$ & $13 \%$ & $0 \%$ & $58 \%$ & $33 \%$ & $8 \%$ & $0 \%$ & $14 \%$ & $82 \%$ & $4 \%$ & $0.0092^{* *}$ \\
\hline people with autism are sad & $7 \%$ & $41 \%$ & $45 \%$ & $7 \%$ & $4 \%$ & $67 \%$ & $21 \%$ & $8 \%$ & $0 \%$ & $43 \%$ & $57 \%$ & $0 \%$ & 0.1152 \\
\hline $\begin{array}{l}\text { the speech of these people is } \\
\text { monotonous as if they were } \\
\text { chanting }\end{array}$ & $14 \%$ & $24 \%$ & $48 \%$ & $14 \%$ & $21 \%$ & $17 \%$ & $46 \%$ & $17 \%$ & $32 \%$ & $29 \%$ & $39 \%$ & $0 \%$ & 0.2699 \\
\hline $\begin{array}{l}\text { people with autism do not } \\
\text { like changes }\end{array}$ & $0 \%$ & $30 \%$ & $30 \%$ & $10 \%$ & $50 \%$ & $21 \%$ & $25 \%$ & $4 \%$ & $89 \%$ & $7 \%$ & $4 \%$ & $0 \%$ & $0.0013^{* *}$ \\
\hline
\end{tabular}

All respondents from France chose the statement that the treatment of autism should be started before the age of 3. A similar opinion was expressed by $86.7 \%$ of respondents from Poland and $83.3 \%$ from Belarus. Starting the therapy before the age of 5 was preferred by $13.3 \%$ of parents from Poland and $4.2 \%$ from Belarus, and after 7 years of age $-4.2 \%$ of respondents from Belarus. $8.3 \%$ of Belarusians parents considered the time before puberty to be optimal to start the treatment. The distribution of responses did not differ significantly between the countries ( $p=0.0588)$.

The views of the respondents from individual countries on the scope of therapy of a sick child were different. $50 \%$ of parents from Poland, $88 \%$ from Belarus and $89.3 \%$ from France $\left(\mathrm{p}=0.0005^{* * *}\right)$ preferred to receive the preparation in the form of explaining the child's behaviour. Extension of forms of contact with a child was emphasized by $33.3 \%$ of parents from Poland, $68 \%$ from Belarus and $57.1 \%$ from France $(\mathrm{p}=0.0295 *)$. Stimulation of the child for social contacts was indicated by $66.7 \%$ of respondents from Poland, $92 \%$ from Belarus and $71.4 \%$ from France ( $\mathrm{p}=0.725) .30 \%$ of parents from Poland, $72 \%$ from Belarus and 53.6\% from France $\left(\mathrm{p}=0.0076^{* *}\right)$ were in favour of pharmacological treatment. Only $6.7 \%$ of respondents from Poland $(p=1636)$ claimed that the child cannot be cured, and $16.7 \%$ had a dilemma of which answer to choose $\left(\mathrm{p}=0.0091^{* *}\right)$.

The majority of Polish (86.7\%) and French (78.6\%) parents believed that the diet is an effective secondary treatment in the case of autism, which is a false assumption. Only $8 \%$ of Belarusian parents expressed this opinion. $56 \%$ of the Belarusian parents and $10.7 \%$ of the respondents from France doubted the effectiveness of the diet, whereas $13.3 \%$ of respondents from Poland, 36\% from Belarus and 10.7\% from France had a problem with the response. The distribution of responses differed significantly between the countries ( $\left.p=0.0000^{* * *}\right)$.

Similarly, Polish parents (41.4\%) believed that there is an effective medication which helps to neutralize the symptoms of autism. Parents from other countries were more restrained in their optimism, because $4 \%$ of parents from Belarus and 14.3\% from France thought so. A significantly different opinion was expressed by $27.6 \%$ of respondents from Poland, 32\% from Belarus and $46.4 \%$ from France. $31 \%$ of respondents from Poland, $64 \%$ from Belarus and 39.3\% from France were undecided on the above issue. The distribution of responses differed significantly between the countries $\left(p=0.0048^{* *}\right)$. 
Parents from Poland (69\%) and Belarus (76\%) were mostly convinced that autism cannot be cured completely. Parents from France (39.3\%) believed so. 44.9\% of parents from France, 17.2\% from Poland and $4 \%$ from Belarus were convinced that autism can be cured completely. An unequivocal answer was not given by $13.8 \%$ of respondents from Poland, $20 \%$ from Belarus and $17.9 \%$ from France. The distribution of responses differed significantly between the countries ( $\left.\mathrm{p}=0.0101^{*}\right)$.

Most parents $(56.7 \%$ from Poland, 76\% from Belarus, 96.4\% from France) were aware that one-time examination of a child was not enough. A different opinion was expressed by $30 \%$ of respondents from Poland, $8 \%$ from Belarus and 3.6\% from France. 13.3\% of respondents from Poland and 16\% from Belarus had a problem with answering this question. The distribution of responses differed significantly between the countries $(\mathrm{p}=$ $0.0043^{*}$ ).

It was concluded that there is a strong differentiation in the sources of knowledge about autism that were used by parents from three countries. The Internet was indicated by $83.3 \%$ of parents from Poland, $52 \%$ from Belarus and $46.4 \%$ from France ( $\mathrm{p}=0.0079^{* *}$ ). The psychologist was mentioned by $36.7 \%$ of parents from Poland, $76 \%$ from Belarus and $67.9 \%$ from France $\left(\mathrm{p}=0.0065^{* *}\right)$. As a preferred medium the Internet was indicated by $76.6 \%$ of parents from Poland, $36 \%$ from Belarus and 39.3\% from France $\left(p=0.0029^{* *}\right)$, a doctor $-43.3 \%$ of parents from Poland, $48 \%$ from Belarus and $64.3 \%$ from France $(p=0.252)$, the press $-60.3 \%$ of parents from Poland, 20\% from Belarus and $21.4 \%$ from France $\left(\mathrm{p}=0.0015^{* *}\right)$, and a nurse $-3.3 \%$ of parents from Poland and $28.6 \%$ from France $\left(\mathrm{p}=0.0010^{* * *}\right)$.

The vast majority of respondents (90\% from Poland, 100\% from Belarus, 92.9\% from France) felt the need to deepen their knowledge about autism. 3.3\% of parents from Poland and 3.6\% from France did not feel such a need, and $6.7 \%$ of respondents from Poland and 3.6\% from France had a problem with the response. The distribution of responses did not differ significantly between the countries $(p=0.6104)$.

There were very clear statistical differences in the choice of the preferred educator by parents depending on the country of residence. The psychologist was preferred by $56.7 \%$ of parents from Poland, $88 \%$ from Belarus and $57.1 \%$ from France $\left(\mathrm{p}=0.0228^{*}\right)$. The family doctor was indicated by $53.3 \%$ of respondents from Poland, $12 \%$ from Belarus and 53.6\% from France ( $\left.\mathrm{p}=0.0020^{* *}\right)$. The paediatrician was mentioned by $73.3 \%$ of respondents from Poland, 20\% from Belarus and 17.9\% from France ( $\left.\mathrm{p}=0.0000^{* * *}\right) .43 .3 \%$ of parents from Poland and $40 \%$ from Belarus ( $\mathrm{p}=0.0003^{* * *}$ ) indicated a pedagogue as an educator and a nurse $-33.3 \%$ of parents from Poland, $4 \%$ from Belarus and $21.4 \%$ from France ( $\left.\mathrm{p}=0.0270^{*}\right) .10 \%$ of respondents from Poland and $8 \%$ from Belarus $(\mathrm{p}=0.2460)$ were undecided on the above issue.

Parents preferred very different forms of transfer of knowledge. An individual interview was indicated by $60 \%$ of parents from Poland, $44 \%$ from Belarus and $78.6 \%$ from France ( $\mathrm{p}=0.0350 *$ ). Lecture - $53.3 \%$ of parents from Poland, 284\% from Belarus and 46.4\% from France ( $\mathrm{p}=0.1554$ ). Film - $60 \%$ of parents from Poland, $16 \%$ from Belarus and $28.6 \%$ from France ( $\mathrm{p}=0.0019^{* *}$ ). Leaflets/brochures - 30\% of parents from Poland, $20 \%$ from Belarus and $14.3 \%$ from France ( $\mathrm{p}=0.3386)$, and wall leaflets $-16.7 \%$ of parents from Poland and $10.7 \%$ from France ( $p=0.1105) .16 .7 \%$ of parents from Poland and 16\% from Belarus had a problem with unequivocal response $(\mathrm{p}=0.0763)$.

The hypothesis put forward at the beginning of the study assumed that parents were largely interested in gaining the knowledge about their child's disease, mainly in the field of forms of therapy. On the basis of the results of the study, different views of respondents from different countries on the scope of treatment of a sick child were observed, e.g. Polish respondents barely considered as important the preparation of parents aimed at gaining understanding of their child's behaviour, while the treatment aspect was indicated by almost $90 \%$ of respondents from the other two countries.

\section{Discussion}

Raising an autistic child is not a simple or easy matter, however, it is not devoid of much joy. Nevertheless, people struggling with this problem need to be able to obtain the adequate knowledge about the condition and the support from their environment.

The majority of autistic patients' present behaviours that can cause significant stress in their families. Therefore, parents need to learn many strategies to support their child. Understanding the experiences of parents of children with autism is essential for the development and delivery of parental support systems.

Koydemir-Ozden and Tosun [14] examined 13 mothers (aged 30-40 years) of children with autism (aged 7 to 14 years). The analysis of the research allowed to identify categories and sub-categories, such as: reaction to a child's disability, experience of stress and burnout, involvement in the child's education and evaluation of measures dealing with the child's education and distinguished several zones within which categories and sub-categories 
emerged [14]. Zone I - mother's understanding of disability [14], consists of two categories 1-description of autism by the mother and 2 - a degree of information on autism and ways of obtaining further information about it. Zone II - responding to disability [14], consist of typical reactions to the diagnosis experienced by parents: shock, rejection, denial, depressive states, sadness. In this zone, further categories have been distinguished: 3 - stress and burnout and ways of coping with stress, 4 - inclusion of the child in education, 5 - evaluation of the Special Education Centre and teachers (committed, helpful, compassionate), 6 - the impact the child has on the personal life of the mother and 7- hopes and expectations for the future (for both mothers and children).

Konwińska et al. [15] included 346 people aged 16 to 18 years in the study and their aim was to assess their knowledge about autism. Every second woman was able to name at least three features of this disease (55\%), while only $37 \%$ of men knew what autism was. The awareness of the respondents about autism is similar to the lack of knowledge about it. The study has shown that high school students have disturbingly high deficits in the knowledge about autism [15].

189 people aged 16 to 19 years participated in the study by Marecka [16], and it was found that the women's awareness of this disease was significantly higher (38.6\%) than men's (27.3\%). However, the above did not change the fact that only $36 \%$ of young people were able to name at least three symptoms of autism [16].

Unfortunately, in the present study it also has been concluded that the parents of autistic children, regardless of the country, showed a low level of knowledge about autism.

Kurpas et al. [17], from February to April 2009, were conducting surveys among parents of children with autistic disorders. The study involved 35 parents of children with comprehensive developmental disorders - 29 mothers and 6 fathers. Parents expressed the need to cooperate with a psychologist. They emphasized that such help was needed for all family members.

In the present study there were clear statistical differences in the choice of a psychologist as an educator of parents, hence such form of help was preferred by $56.7 \%$ of parents from Poland, 88\% from Belarus and $57.1 \%$ from France and as a source of knowledge about autism - 36.7\% of parents from Poland, $76 \%$ from Belarus and $67.9 \%$ from France.

Palka [18], in their studies on family support for children with autism spectrum, point to the most frequently asked questions of family assistant nurses in making critical decisions, information on available therapies and planning the future of a sick child. The authors [18] conclude that the families of children with autism, after receiving professional information support from nurses, are able to understand the nature of their child's disability and meet its challenges and learn to function well.

In the present study, 33.3\% of parents from Poland, $4 \%$ from Belarus and $21.4 \%$ from France indicated a nurse as a source of knowledge about the child's disease, while 3.3\% of parents from Poland and $28.6 \%$ from France perceived them only as an educator.

$90 \%$ of all parents in the Bodora study expected to obtain reliable information and guidance from the specialists [19]. All 25-35 year olds, $95 \%$ of 36-45 year olds and $83 \%$ of 46 year olds and above needed to obtain complete, true and comprehensive information [19]. However, the lack of cooperation of specialists in the area was felt by $66 \%$ of the total number of respondents, and the coldness of professionals - $56 \%$ of them. A significant role of mass media in familiarizing with the problem of autistic children and their families was indicated by $80 \%$ of all participants in the Bodora study, including the largest number of parents aged 36-45 years (85\%). Parents in the 25-35 age group also pointed to the importance of the mass media in making the public aware of what autism is and what it means (67\%), and 79\% of parents in the age group of 46 and above also believed that the media can help to solve problems of coexistence with an autistic child [19].

In the study conducted by Konwińska et al. [15] 72\% of women and 51\% of men were of the opinion that the media should definitely be interested in the problem of autism, while in Marecka study [16] - 60\% of women and $27.3 \%$ of men surveyed indicated the answer: "The media should definitely be interested in issues related to autism", and $3.7 \%$ of the respondents did not want the subject of autism to be addressed in the media at all.

On the basis of the present study, it was found that the vast majority of respondents ( $90 \%$ from Poland, $100 \%$ from Belarus, 92.9\% from France) felt the need to deepen their knowledge about autism. However, there was a strong diversity in the sources of knowledge about autism, which were used by parents from three countries - Poles were most likely to use the Internet and information in the media, whereas Belarusians and French a specialist (psychologist, doctor, nurse).

In many countries, specialist centres are being established, such as the "GiantSteps" Autistic Children's Therapy Centre in Canada, or the St. Colman's School in the United States, whose educational programme covers not only children, but also their parents [12, 20,21]. The counselling, awareness-rising, education, and support for families influence the better functioning of families with autistic children and improve the quality of their lives [12, 20, 21]. 
In Manchester, for Mockett [22], since early 1998, the standard of conduct is early intervention and interdisciplinary cooperation of specialists (psychiatry, paediatrics, speech therapy, psychology, physiotherapy) with parents who have the opportunity to participate in similar programs every year.

The purposefulness of the above is justified, e.g. by the results of the research conducted by Konwińska et al. [15] and Marecka et al. [16] showed that young people participating in sensory workshops had little knowledge about autism before the workshops, and it significantly increased after the classes. Disseminating the knowledge about autism is very important. The fact that this is still a neglected issue may be worrying

In Poland, as noted by Czenczek et al. [13] under the auspices of associations and foundations dealing with autistic children, schools are also starting to operate, in which special branches for autistic children are organized, however, still too little support is directed towards their parents and guardians.

Nevertheless, it should also be remembered that every child with autistic disorder is exceptional and unique, which is why parents must show their great sensitivity, openness and perceptiveness in order to be able to see and understand the signals transmitted to them by their children. The above may be summarised through the words of Igancio Estrada - "If children are unable to learn in the way we teach them, perhaps we should start to teach them in the way they learn."

\section{Conclusions}

1. The parents of autistic children, regardless of the country, showed a low level of knowledge about autism.

2. The vast majority of the respondents declared the desire to deepen their knowledge about autism, expressing their preference to have an individual conversation with an educator.

\section{Acknowledgements}

The authors would like to thank the parents associated in the "Wspólny Świat" Association from the Centre for Therapy and Diagnostics of Autistic Children in Biała Podlaska, Ms. Anna Chwałek - Head of the Centre and Ms. Marzena Szydłowska-Grajcar - Vice President of the Association, for their help in conducting this study; Ms. Oksana Trafimiuk and the parents of children affiliated with Corrective Center - development education and rehabilitation in Brest as well as those parents associated in the Association of Parents of Children with Autism in Niort, in the Deux Sevres Department-Centre Hospitalier, Niort Cedex.

\section{References:}

1. Pisula E, Danielewicz D. [Chosen forms of therapy and rehabilitation of people with autism]. Kraków: Oficyna Wyd. Impuls; 2005 (in Polish).

2. Błeszyński J. [Development support for people with autism - theory, methodology, examples]. Kraków: Impuls; 2004. p. 19-37 (in Polish).

3. Cappe E, Wolff M, Bobct R, Adricn JL. Quality of life: a key variable to consider in the evaluation of adjustment in parents of children with autism spectrum disorders and in the development of relevant support and assistance programmes. Qual Life Res. 2011; 20(8): 1279-94.

4. Lotter V. Epidemiology of autistic conditions in young children. Prevalence. Social Psychiatry. 1966; 1: 124137. https://doi.org/10.1007/BF00584048

5. Markiewicz K. [Communication possibilities of autistic children]. Lublin: Wyd. Uniwersytetu Marii CurieSkłodowskiej; 2004. p. 55-56 (in Polish).

6. Fombonne E. Epidemiology of pervasive developmental disorders. Pediatr. Res. 2009; 65: 591-598. https:// doi.org/10.1203/PDR.0b013e31819e7203

7. Kościelska M. [Essential problems for autism diagnosis related to the ambiguity of the meaning]. Kwartalnik Informacyjny Krakowskiego Oddziału Krajowego Stowarzyszenia Autyzmu. 1995; 5. (in Polish).

8. Greenberg J, Chou R, Hong J, Krauss M, Seltzer M. The effect of quality of the relationship between mothers and adult children with schizophrenia, autism, or Down syndrome on maternal well-being: the mediating role of optimism. Am. J. Orthopsychiatry. 2004; 74: 14-25. https://doi.org/10.1037/0002-9432.74.1.14

9. Bendixen RM, Elder JH, Donaldson S, Kairalla JA, Valcante JA, Ferdig RE. Effects of a father-based in-home intervention on perceived stress and family dynamics in parents of children with autism. Am J Occup Ther. 2011; 65(6): 679-87. https://doi.org/10.5014/ajot.2011.001271

10. Mieres AC, Kirby RS, Armstrong KH, Murphy TK, Grossman L. Autism spectrum disorder: an emerging opportunity for physical therapy. Pediatr Phys Ther. 2012; 24(1): 31-7.

https://doi.org/10.1097/PEP.0b013e31823e06d1 
11. Kosakowski C, Krause A. [Rehabilitation, care and special education in the prerspective of change]. Olsztyn: Wydawnictwo Uniwersytetu Warmińsko-Mazurskiego; 2004. p. 329-335 (in Polish).

12. Head LS, Abbeduto L. Recognizing the role of parents in developmental outcomes: a systems approach to evaluating the child with developmental disabilities. Ment Retard Dev Disabil Res Rev. 2007; $13(4): 293-301$. https://doi.org/10.1002/mrdd.20169

13. Czenczek E, Szeliga E, Przygoda $Ł$. [Quality of life among parents of children with autism]. Przegląd Medyczny Uniwersytetu Rzeszowskiego i Narodowego Instytutu Leków w Warszawie. 2012; 10(4): 446-453 (in Polish).

14. Koydemir-Ozden S, Tosun I. A qualitative approach to understanding Turkish mothers of children with autism: implications for counselling. Australian Journal of Guadience and Counselling. 2010; 20: 55-68. https://doi.org/10.1375/ajgc.20.1.55

15. Konwińska A, Tomiak K, Cycuła S. [Autistically gifted. The wave of solidarity. Research study report]. Zielona Góra: Fundusz Inicjatyw Obywatelskich; 2006. p. 1-27 (in Polish).

16. Marecka M. [Reportfrom the research studyamong secondary-school students].Zielona Góra: Stowarzyszenie Pomocy Osobom Autystycznym „Dalej Razem”; 2008. p. 1-28 (in Polish).

17. Kurpas D, Skoberla M, Sapilka B, Steciwko A. [Relations in the family of a child with autistic disorder]. Med. Prim. CareRev. 2009; 11: 379-381 (in Polish).

18. Palka S. [Methodology. Studies. Pedagogical practice]. Gdańsk: Gdańskie Wydawnictwo Psychologiczne; 2006 (in Polish).

19. Bodora G. [Determinants of life together with an autistic child - own studies] [Internet]. [cited 2012 Apr 5]. Available from: http://www.dzieci.bci.pl/strony/autism/Determinanty.htm

20. Błaszczyk S. [Socio-psychological functioning of the parents and siblings of an autistic child]. Problemy Opiekuńczo Wychowawcze. 2008; 3: 40-44 (in Polish).

21. Strauss K, Vicari S, Vaieri G, D'Elia L. Parent inclusion in early intensive behavioral intervention: the influence of parental stress, parent treatment fidelity and parent-mediated generalization of behavior targets on child outcomes. Res Dev Disabil. 2012; 33(2): 688-703. https://doi.org/10.1016/j.ridd.2011.11.008

22. Mockett M, Khan J, Teodosiou L. Parental perceptions of Manchester Service for Autistic Spectrum Disorders. International Journal of Family Medicine. 2011; 601979: about 6 pages. https://doi.org/10.1155/2011/601979 